\title{
An Ecological Study of Free-living Marine Nematodes in Teluk Awar, Sarawak, Malaysia
}

\author{
CHENG-ANN CHEN* $*^{1,2}$, SHABDIN MOHD LONG ${ }^{2} \&$ NORLIANA MOHD ROSLI' ${ }^{2,3}$ \\ ${ }^{1}$ Borneo Marine Research Institute, Universiti Malaysia Sabah, Jalan UMS, 88400 Kota Kinabalu, Sabah, Malaysia \\ ${ }^{2}$ Department of Aquatic Science, Faculty of Resource Science and Technology,Universiti Malaysia Sarawak, 94300 \\ Kota Samarahan, Sarawak, Malaysia \\ ${ }^{3}$ Department of Biology, Faculty of Science and Mathematics, Universiti Pendidikan Sultan Idris, 35900 Tanjong \\ Malim, Perak Darul Ridzuan, Malaysia
}

\begin{abstract}
The community structure of marine nematode assemblages in the southern-west of Borneo was investigated with special focus on the horizontal distribution from high tide to subtidal area. A transect study had been conducted in Teluk Awar. Nine stations were chosen from the Mean High Water Neap to Mean Low Water Neap level. The physico-chemical characteristic of water and sediments were determined both ex situ. One-way ANOVA showed that the environmental variables among stations were significantly different (except chlorophyll $a$ and total organic matter). Multi-dimensional scaling demonstrated three distinct patterns among the stations while dendrogram showed high dissimilarity percentage in the species distribution among stations. In conclusion, the results showed that environmental variables such as clay, total organic matter and temperature were affecting the nematode distribution pattern in Teluk Awar.
\end{abstract}

Keywords: Sarawak, marine nematode, horizontal, intertidal, feeding type

\section{INTRODUCTION}

Nematodes which are sensitive to environmental perturbations have become a popular subject to study in relation to pollution. This is due to their characteristics such as occurring in large numbers, relatively stationary life habits, short generation times, benthic larvae and intimate association with sediments which are known to accumulate various contaminants, nematodes (Warwick et al. 1990; Warwick 1993). Most of the studies on free-living marine nematodes had been carried out in the temperate countries such as horizontal studies (Tietjen 1976; Gheskiere et al. 2004), ecological studies (Forster 1997; Vermeeven et al. 2004) and environmental pollution impact studies (Mahmoudi et al. 2005, 2006; Moreno et al. 2008). Although marine nematodes comprise a large fraction of marine benthic communities, limited information is available on their assemblages from Malaysian waters.

According to Chong (2000), Sarawak River Regulation Study identified that the water quality for Sarawak River fell short of Class IIB standard in accordance with the Interim National Water Quality Standard (INWQS) in 1996. A comparison on the water quality of Sarawak River in 1996 and 2000 showed that there has been a significant deterioration in terms of dissolved oxygen (DO) (from 5.0 to $3.41 \mathrm{mg} \mathrm{l}^{-1}$ ) and total coliform counts (from 4,500 to 16,000 counts $100 \mathrm{ml}^{-1}$ ). These indicate that the water is not suitable for any activities that have contact with the water. In 2005, the water quality of the Sarawak River is still categorized in Class IIB (NREB 2006).

Teluk Awar is located in Muara Tebas (Sarawak) at the South-west coast of Borneo. Teluk Awar with an area of $6.9 \mathrm{~km}^{2}$ (approximately $26 \mathrm{~km}$ from Kuching) was chosen for the present study due to several reasons. It is located at the river mouth of the Sarawak River that brings along the excess disposal from the household or factories that are located along the river. Besides that, the distribution study of the meiofauna especially the free-living marine nematode in Teluk Awar is still scarce.

The aims of this study were to profile the horizontal distribution of the marine nematode from the high

*Corresponding author: chengann@ums.edu.my 
tide to subtidal area and their relationship with abiotic and biotic factors.

\section{MATERIALS AND METHODS}

A pilot study which had been carried out on $17^{\text {th }}$ June 2008 showed that 3 replicates together with a depth of $15 \mathrm{~cm}$ samples were enough to represent the nematode density of each station (Chen, unpublished data). On the $23^{\text {rd }}$ of July 2008, a quantitative sampling was carried out at nine stations during low tide (Figure 1). The distance between each station from the Mean High Water Neap (MHWN) to subtidal area was approximately 300 $\mathrm{m}$. Seven stations were located in the intertidal while the last two stations were in the subtidal area. Mangrove species such as Avicenia marina, Rhizophora mucronata, R. apiculata and Casuarina equisetifolia were recorded in station 2 during the sampling.

Physico-chemical parameters of the waters such as the $\mathrm{pH}$, salinity, dissolved oxygen (DO), oxidation reduction potential (ORP or called Eh) $(\mathrm{mV})$ and temperature were measured in situ using the water quality meter, HORIBA U20-XD. Sediment samples were taken randomly in the intertidal area using Perspex tube corer $(2.5 \mathrm{~cm}$ cross-section) while subtidal sediment samples were collected by SCUBA diver with piston style corer. All samples were stored immediately in cooler box with ice and brought back to laboratory for nematode density study (3 replicates), total organic matter (TOM) analysis (2 replicates), chlorophyll $a$ (chl a) analysis (3 replicates) and particle size analysis (1 replicate). Samples for nematode density study were fixed immediately in $5 \%$ formalin which was diluted using site water.

Nematode extraction and preservation were based on the methods described in Sommerfield et al. (2005). Nematodes were isolated from samples and transferred to a glass cavity block containing glycerine (5\%), pure ethanol (5\%) and freshwater (90\%). After dehydration, nematodes were transferred into a drop of anhydrous glycerine on a slide prior to mounting. Every nematode in each replicate was counted for the nematode density study. The slide was identified under a high power compound microscope (Olympus BX 51). Pictorial keys (Platt \& Warwick 1983, 1988; Warwick et al. 1998) from the British waters were used for identification. Besides that, each nematode species was assigned to one of the four functional feeding groups (FFG) as mentioned in Giere (2009) on the basis of buccal cavity morphology. TOM was measured using the method proposed by Greiser and Faubel (1988). Chl $a$ analysis was conducted using Wasmund's (1984) method and calculated using the equation given by Jeffrey and Humprey (1975). Particle size analysis was carried out using the methods proposed by Buchanan (1984).

All the statistical analyses were conducted using PRIMER v6 (Clarke \& Warwick 1994).

\section{RESULTS}

\section{Environmental parameters}

One-way ANOVA analysis showed that the salinity of Teluk Awar was significantly different among

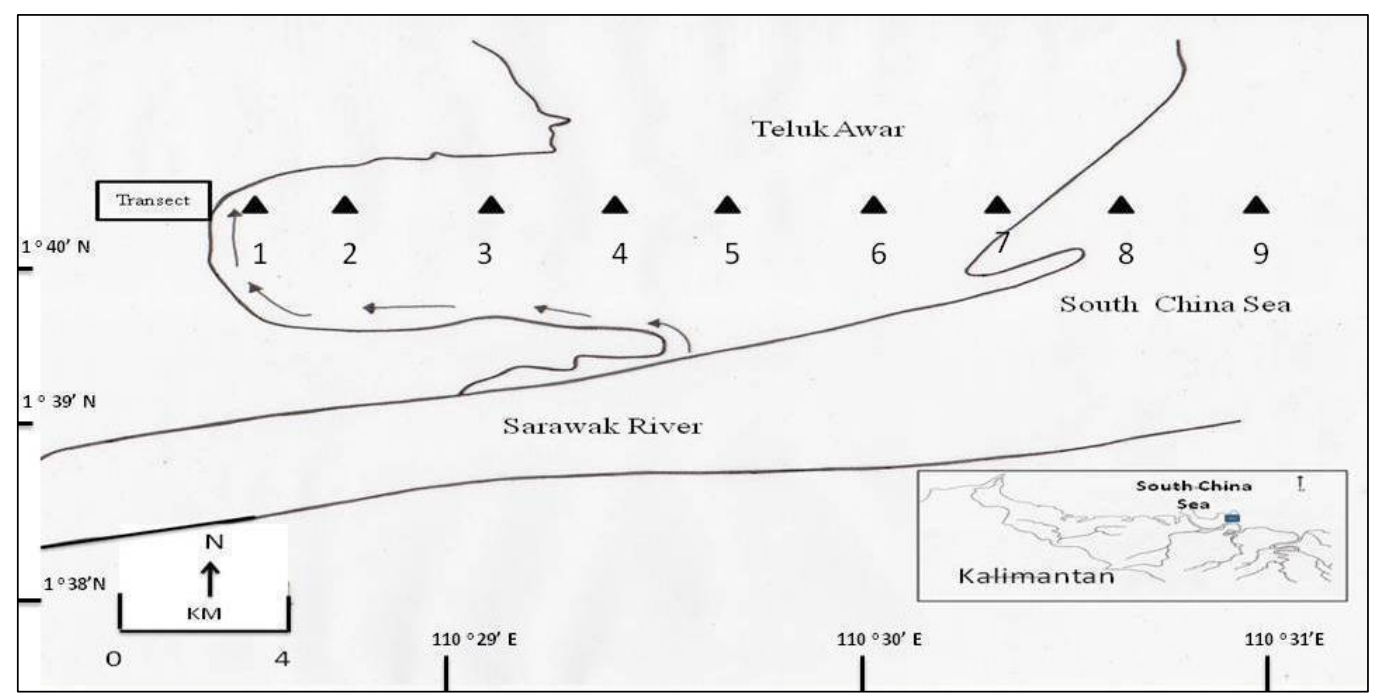

Figure 1: Map showing the location of Sarawak River and Teluk Awar where nematode assemblages were sampled. Arrows represent the influx of freshwater from Sarawak River. 
stations ( $p$-value $<0.001$ ). The lowest salinity level was recorded at station 1 while the highest was at station 4 (Table 1). Temperature was significantly different among stations ( $p$-value $<0.001$ ) and the highest temperature was recorded at station 2 . The ambient temperature decreased from intertidal to subtidal stations.

In the present study, the highest $\mathrm{pH}$ was recorded at station 2 while the lowest was at station 4 (Table 1). The $\mathrm{pH}$ did not fluctuate much among the study stations. Both DO and Eh showed differences between stations ( $p$-value $<0.001$ ). The lowest reading of Eh was recorded at station 1 while the highest was recorded at subtidal stations. The mean Eh reading increased while moving outward from high tide to subtidal area. Lower DO was recorded in the intertidal area compared to the subtidal area. Highest DO was recorded at subtidal stations (3.5 and $3.8 \mathrm{mg} \mathrm{l}^{-1}$ ) while lowest reading was recorded in station 2, 4 and 6. One-way ANOVA showed no significant difference in chl $a$ and TOM concentrations among the stations (p-value: 0.076; 0.096). Chl $a$ was highest in station $3\left(1.52 \mathrm{mg} \mathrm{m}^{-3}\right.$ ) and lowest in the subtidal stations. The highest reading of TOM was recorded in station 6 .

Particle size decreased when moving outward from the MHWN to the MLWN zone (Table 1). Station 1, 3, 4, 5, 7, 8 and 9 were categorized as sandy stations (dominated more than $54 \%$ of the total sediment fraction). The highest percentage of sand fraction was found in station 4 (92.6\%) followed by station 1 (92.3\%), station 3 (84.7\%), station 5 (77.9\%), station 9 (73.5 \%), station 8 (60.3 $\%)$ and station 7 (54.9\%). The remaining stations were characterized by higher percentage of silt and clay fractions. The highest silt and clay contents were recorded in station 2. Mid-tide level stations were mostly dominated by coarser sand. Higher silt and clay fractions were recorded when moving outward towards the low and subtidal stations (except station 2).

Table 1. Mean of environment variables measured at each sampling station in Teluk Awar.

\begin{tabular}{clllllllllll}
\hline \multirow{2}{*}{ ST } & \multicolumn{7}{c}{ Environment Physico-chemical Parameters (abiotic) and biotic factors } \\
\cline { 2 - 11 } & Salinity & Temp & $\mathrm{pH}$ & $\mathrm{DO}$ & Eh & Chl $a$ & TOM & Density & Sand \% & Silt \% & Clay \% \\
\hline 1 & $11.00 \pm 0.00^{\mathrm{a}}$ & $32.97 \pm 0.01^{\mathrm{a}}$ & $9.00 \pm 0.21^{\mathrm{ab}}$ & $0.80 \pm 0.7^{\mathrm{a}}$ & $-47.50 \pm 24.75^{\mathrm{a}}$ & $0.17 \pm 0.00^{\mathrm{a}}$ & $1.14 \pm 0.02^{\mathrm{a}}$ & $284.00 \pm 49.40^{\mathrm{a}}$ & 92.30 & 4.10 & 3.60 \\
2 & $36.00 \pm 0.00^{\mathrm{b}}$ & $35.60 \pm 0.00^{\mathrm{b}}$ & $9.60 \pm 0.01^{\mathrm{c}}$ & $0.40 \pm 0.01^{\mathrm{b}}$ & $82.50 \pm 2.12^{\mathrm{b}}$ & $0.87 \pm 0.44^{\mathrm{a}}$ & $1.42 \pm 0.12^{\mathrm{a}}$ & $37.00 \pm 2.60^{\mathrm{bc}}$ & 5.20 & 88.00 & 6.80 \\
3 & $35.00 \pm 0.00^{\mathrm{c}}$ & $35.14 \pm 0.08^{\mathrm{c}}$ & $9.50 \pm 0.01^{\mathrm{dd}}$ & $0.50 \pm 0.02^{\mathrm{c}}$ & $81.50 \pm 2.12^{\mathrm{b}}$ & $1.52 \pm 1.13^{\mathrm{a}}$ & $1.54 \pm 0.10^{\mathrm{a}}$ & $66.00 \pm 1.00^{\mathrm{b}}$ & 84.70 & 13.40 & 1.90 \\
4 & $39.00 \pm 0.00^{\mathrm{d}}$ & $33.77 \pm 0.06^{\mathrm{d}}$ & $8.90 \pm 0.00^{\mathrm{a}}$ & $0.40 \pm 0.09^{\mathrm{bc}}$ & $81.50 \pm 4.95^{\mathrm{b}}$ & $0.20 \pm 0.20^{\mathrm{a}}$ & $1.48 \pm 0.09^{\mathrm{a}}$ & $3.00 \pm 0.60^{\mathrm{c}}$ & 92.60 & 6.90 & 0.50 \\
5 & $37.00 \pm 0.00^{\mathrm{c}}$ & $35.03 \pm 0.05^{\mathrm{c}}$ & $9.40 \pm 0.04^{\mathrm{dd}}$ & $0.80 \pm 0.02^{\mathrm{a}}$ & $105.50 \pm 2.12^{\mathrm{bc}}$ & $0.10 \pm 0.05^{\mathrm{a}}$ & $1.67 \pm 0.06^{\mathrm{a}}$ & $132.00 \pm 14.10^{\mathrm{d}}$ & 77.90 & 19.40 & 2.70 \\
6 & $38.50 \pm 0.71^{\mathrm{d}}$ & $34.78 \pm 0.08^{\mathrm{c}}$ & $9.50 \pm 0.01^{\mathrm{dd}}$ & $0.40 \pm 0.00^{\mathrm{bc}}$ & $106.00 \pm 1.41^{\mathrm{bc}}$ & $0.47 \pm 0.30^{\mathrm{a}}$ & $1.89 \pm 0.12^{\mathrm{a}}$ & $14.00 \pm 3.00^{\mathrm{c}}$ & 44.20 & 51.10 & 4.70 \\
7 & $37.00 \pm 0.00^{\mathrm{c}}$ & $33.12 \pm 0.02^{\mathrm{a}}$ & $9.40 \pm 0.02^{\mathrm{dd}}$ & $3.40 \pm 0.00^{\mathrm{d}}$ & $139.00 \pm 2.83^{\mathrm{dd}}$ & $0.11 \pm 0.03^{\mathrm{a}}$ & $1.26 \pm 0.07^{\mathrm{a}}$ & $141.00 \pm 5.60^{\mathrm{d}}$ & 54.80 & 40.90 & 4.30 \\
8 & $32.00 \pm 0.00^{\mathrm{f}}$ & $29.65 \pm 0.00^{\mathrm{f}}$ & $9.00 \pm 0.02^{\mathrm{ab}}$ & $3.50 \pm 0.00^{\mathrm{d}}$ & $152.00 \pm 0.00^{\mathrm{d}}$ & $0.06 \pm 0.03^{\mathrm{a}}$ & $1.12 \pm 0.18^{\mathrm{a}}$ & $0.00 \pm 0.00^{\mathrm{c}}$ & 60.30 & 35.70 & 4.00 \\
9 & $34.00 \pm 0.00^{\mathrm{g}}$ & $29.65 \pm 0.00^{\mathrm{f}}$ & $9.20 \pm 0.01^{\mathrm{bd}}$ & $3.80 \pm 0.00^{\mathrm{c}}$ & $141.00 \pm 0.71^{\mathrm{d}}$ & $0.07 \pm 0.01^{\mathrm{a}}$ & $1.41 \pm 0.59^{\mathrm{a}}$ & $7.00 \pm 1.00^{\mathrm{c}}$ & 73.50 & 24.20 & 2.30 \\
\hline
\end{tabular}

* ST - Station; Temp - Temperature $\left({ }^{\circ} \mathrm{C}\right)$; DO - Dissolved Oxygen ( $\left.\mathrm{mg} \mathrm{l}^{-1}\right)$; Chl $a$ - Chlorophyll $a\left(\mathrm{mg} \mathrm{m}^{-3}\right)$; TOM - Total Organic Matter; Density - Nematode (Ind. $10 \mathrm{~cm}^{-2}$ ); Eh - Oxidation Reduction Potential (mV)/ Eh

Mean values with different superscript alphabets in the same column are significantly different ( $p$-value $<0.05)$.

\section{Nematode community}

A total of 22 genera and 63 species of nematodes were identified in Teluk Awar (Table 2). One-way ANOVA analysis showed that the density of marine nematodes was significantly different among stations ( $p$-value $<0.001$ ). The mean densities of nematodes were fairly erratic along the transect (Figure 2a). The list of nematode species together with the percentage of abundance is listed in Table 2.
Station 1 was dominated by Sphaerolaimus macrocirculus, Spilophorella candida and Daptonema tenuispiculum. Higher abundance of Hopperia massiliensis, Diodontolaimus tenuispiculum and Parodontophora pacifica were recorded in station 2. Daptonema hirsutum was mostly found in station 3 followed by Sphaerolaimus gracilis, Sphaerolaimus horrendous and Viscosia erasmi. However, only one species of nematode was found in station 4 (D. hirsutum). 
Table 2: Functional feeding group of each nematode species, and the mean densities (Ind. $10 \mathrm{~cm}^{-2}$ ), percentage contribution by abundance of those species at the 9 study stations in Teluk Awar. Data are restricted to those species which contributed $>0.5 \%$ of the total number of individuals in any stations

\begin{tabular}{|c|c|c|c|c|c|c|c|c|c|c|}
\hline \multirow[b]{2}{*}{ Nematode species } & \multirow{2}{*}{$\begin{array}{l}\text { Feeding } \\
\text { Group }\end{array}$} & \multicolumn{9}{|c|}{ Station } \\
\hline & & 1 & 2 & 3 & 4 & 5 & 6 & 7 & 8 & 9 \\
\hline Belbolla asupplementata & $2 \mathrm{~A}$ & - & - & - & - & - & - & $\begin{array}{l}\mathrm{a}_{2.0} \\
(1.4)\end{array}$ & - & - \\
\hline Daptonema australis & 1B & $<1(<1)$ & - & - & - & - & - & - & - & - \\
\hline Daptonema conicum & $1 \mathrm{~B}$ & $21.0(7.4)$ & - & - & - & - & - & $4.0(2.8)$ & - & - \\
\hline Daptonema frabeculosom & 1B & - & - & - & - & - & - & $1.0(0.7)$ & - & - \\
\hline Daptonema hirsutum & $1 \mathrm{~B}$ & - & - & $\begin{array}{c}43.0 \\
(65.0)\end{array}$ & $\begin{array}{c}7.0 \\
(100.0)\end{array}$ & $\begin{array}{c}29.0 \\
(22.0)\end{array}$ & - & $\begin{array}{c}50.0 \\
(35.0)\end{array}$ & - & - \\
\hline Daptonema normandicus & $1 \mathrm{~B}$ & - & - & - & - & $\begin{array}{l}21.0 \\
(16.0)\end{array}$ & - & - & - & - \\
\hline Daptonema procerum & 1B & - & - & - & - & - & - & $3.0(2.1)$ & - & - \\
\hline Daptonema tenuispiculum & 1B & $\begin{array}{l}29.0 \\
(10.0)\end{array}$ & - & - & - & - & - & $\begin{array}{l}13.0 \\
(9.2)\end{array}$ & - & - \\
\hline Daptonema trabeculosom & 1B & - & - & - & - & - & - & $7.0(5.0)$ & - & - \\
\hline Daptonema vicinus & $1 \mathrm{~B}$ & - & - & $3.0(4.5)$ & - & - & - & - & - & - \\
\hline Desmolorenzenia spec & $1 \mathrm{~A}$ & - & - & - & - & - & - & - & - & $\begin{array}{c}1.0 \\
(14.0)\end{array}$ \\
\hline $\begin{array}{l}\text { Diodontolaimus } \\
\text { tunuispiculum }\end{array}$ & $2 \mathrm{~A}$ & - & $\begin{array}{c}14.0 \\
(38.0)\end{array}$ & - & - & - & - & - & - & - \\
\hline Ditlevsenella sp & $2 \mathrm{~B}$ & - & - & - & - & - & - & $2.0(1.4)$ & - & - \\
\hline Hopperia australis & $2 \mathrm{~A}$ & $3.0(1.1)$ & - & - & - & - & - & - & - & - \\
\hline Hopperia massiliensis & $2 \mathrm{~A}$ & - & $\begin{array}{c}16.0 \\
(43.0)\end{array}$ & - & - & $7.0(5.3)$ & - & - & - & - \\
\hline Marylynnia sp & $2 \mathrm{~A}$ & $21.0(7.4)$ & - & - & - & - & - & - & - & - \\
\hline Oxyonchus australis & $2 \mathrm{~B}$ & - & - & - & - & - & - & - & - & $\begin{array}{c}2.0 \\
(29.0)\end{array}$ \\
\hline Oxystomina asetosa & $1 \mathrm{~A}$ & - & - & - & - & $<1(<1)$ & - & - & - & - \\
\hline Oxystomina elongata & $1 \mathrm{~A}$ & $<1(<1)$ & - & - & - & $<1(<1)$ & - & - & - & - \\
\hline Oxystomina vespertilio & $1 \mathrm{~A}$ & - & - & $<1(<1)$ & - & - & - & - & - & - \\
\hline $\begin{array}{l}\text { Paradontophora } \\
\text { brevamphida }\end{array}$ & $2 \mathrm{~A}$ & $14.0(4.9)$ & - & - & - & - & - & - & - & - \\
\hline Paradontophora pacifica & $2 \mathrm{~A}$ & $4.0(1.4)$ & - & - & - & - & - & - & - & - \\
\hline $\begin{array}{l}\text { Paradontophora } \\
\text { xenotricha }\end{array}$ & $2 \mathrm{~A}$ & $16.0(5.6)$ & - & - & - & - & - & - & - & - \\
\hline $\begin{array}{l}\text { Paramesonchium } \\
\text { belgicum }\end{array}$ & $2 \mathrm{~A}$ & - & - & - & - & - & - & $1.0(0.7)$ & - & - \\
\hline Paramesonchium seriale & $2 \mathrm{~A}$ & - & - & - & - & $1.0(0.8)$ & - & - & - & - \\
\hline Parodontophora pacifica & $2 \mathrm{~A}$ & - & $\begin{array}{c}6.0 \\
(16.0)\end{array}$ & - & - & - & - & - & - & - \\
\hline $\begin{array}{l}\text { Parodontophora } \\
\text { quadristicha }\end{array}$ & $2 \mathrm{~A}$ & - & - & $2.0(3.0)$ & - & - & - & - & - & - \\
\hline $\begin{array}{l}\text { Parodontophora } \\
\text { xenoticha }\end{array}$ & $2 \mathrm{~A}$ & - & - & $<1(<1)$ & - & - & - & - & - & - \\
\hline Pierrickia aequalis & $1 \mathrm{~A}$ & $2.0(0.7)$ & - & - & - & $8.0(6.1)$ & - & - & - & - \\
\hline Pierrickia vitielloi & $1 \mathrm{~A}$ & - & - & - & - & $7.0(5.3)$ & $\begin{array}{c}7.0 \\
(50.0)\end{array}$ & - & - & - \\
\hline $\begin{array}{l}\text { Polygastrophora } \\
\text { attenuata }\end{array}$ & $2 \mathrm{~B}$ & - & - & - & - & - & - & $<1(<1)$ & - & - \\
\hline $\begin{array}{l}\text { Polygastrophora } \\
\text { omercooperi }\end{array}$ & $2 \mathrm{~B}$ & - & - & - & - & - & - & $6.0(4.3)$ & - & - \\
\hline $\begin{array}{l}\text { Polygastrophora } \\
\text { setembulba }\end{array}$ & $2 \mathrm{~B}$ & - & - & - & - & - & - & $2.0(1.4)$ & - & - \\
\hline $\begin{array}{l}\text { Promonhystera } \\
\text { tricuspidata }\end{array}$ & 1B & - & - & - & - & $3.0(2.3)$ & - & - & - & - \\
\hline Sabatiera celtica & $1 \mathrm{~B}$ & - & - & - & - & - & - & $<1(<1)$ & - & - \\
\hline Sabatiera heterura & 1B & - & - & - & - & - & $\begin{array}{c}4.0 \\
(28.6) \\
\end{array}$ & - & - & - \\
\hline
\end{tabular}




\begin{tabular}{|c|c|c|c|c|c|c|c|c|c|c|}
\hline Sabatiera intermissa & 1B & - & - & - & - & $7.0(5.3)$ & - & $<1(<1)$ & - & - \\
\hline Sabatiera pomarei & $1 \mathrm{~B}$ & - & - & - & - & - & - & $<1(<1)$ & - & - \\
\hline Sabatiera splendens & $1 \mathrm{~B}$ & - & - & - & - & - & - & $<1(<1)$ & - & - \\
\hline Sabatieria paradoxa & $1 \mathrm{~B}$ & - & - & - & - & - & $\begin{array}{c}1.0 \\
(7.14)\end{array}$ & - & - & - \\
\hline Sabatieria stekhoven & $1 \mathrm{~B}$ & $11.0(3.9)$ & - & - & - & - & - & - & - & - \\
\hline Setosabatieria hilarula & $1 \mathrm{~B}$ & - & - & - & - & - & - & $1.0(0.7)$ & - & - \\
\hline Sphaerolaimus horrendus & $2 \mathrm{~B}$ & - & - & $4.0(6.1)$ & - & - & - & - & - & - \\
\hline Sphaerolaimus balticus & $2 \mathrm{~B}$ & - & $<1(<1)$ & - & - & - & - & - & - & - \\
\hline Sphaerolaimus caspius & $2 \mathrm{~B}$ & $<1(<1)$ & - & - & - & - & - & - & - & - \\
\hline Sphaerolaimus gracilis & $2 \mathrm{~B}$ & $13.0(4.6)$ & - & $8.0(12.0)$ & - & - & - & - & - & - \\
\hline Sphaerolaimus islandicus & $2 \mathrm{~B}$ & $1.0(0.4)$ & $1.0(2.7)$ & - & - & - & - & - & - & - \\
\hline $\begin{array}{l}\text { Sphaerolaimus } \\
\text { macrocirculus }\end{array}$ & $2 \mathrm{~B}$ & $\begin{array}{c}86.0 \\
(30.0)\end{array}$ & - & $<1(<1)$ & - & - & - & $\begin{array}{c}18.0 \\
(13.0)\end{array}$ & - & - \\
\hline Sphaerolaimus pacificus & $2 \mathrm{~B}$ & $21.0(7.4)$ & - & - & - & - & - & - & - & - \\
\hline Spilophorella candida & $2 \mathrm{~A}$ & $\begin{array}{c}36.0 \\
(13.0)\end{array}$ & - & - & - & - & - & $\begin{array}{l}14.0 \\
(9.9)\end{array}$ & - & - \\
\hline Thalassomonhystera sp & $1 \mathrm{~A}$ & - & - & - & - & - & - & - & - & $\begin{array}{c}3.0 \\
(43.0)\end{array}$ \\
\hline Trichotheristus erectus & $1 \mathrm{~A}$ & - & - & - & - & $\begin{array}{c}21.0 \\
(16.0)\end{array}$ & - & - & - & - \\
\hline Trichotheristus floridanus & $1 \mathrm{~A}$ & - & - & - & - & - & - & $\begin{array}{l}14.0 \\
(9.9)\end{array}$ & - & - \\
\hline Viscosia abyssorum & $2 \mathrm{~B}$ & $<1(<1)$ & - & - & - & $<1(<1)$ & - & - & - & - \\
\hline Viscosia antartica & $2 \mathrm{~B}$ & - & - & - & - & $7.0(5.3)$ & $\begin{array}{c}2.0 \\
(14.3)\end{array}$ & - & - & - \\
\hline Viscosia cobbi & $2 \mathrm{~B}$ & - & - & $2.0(3.0)$ & - & $9.0(6.8)$ & - & - & - & - \\
\hline Viscosia erasmi & $2 \mathrm{~B}$ & - & - & $4.0(6.1)$ & - & - & - & - & - & - \\
\hline Viscosia langrunensis & $2 \mathrm{~B}$ & $5.0(1.8)$ & - & - & - & $6.0(4.5)$ & - & - & - & - \\
\hline Viscosia leptolaima & $2 \mathrm{~B}$ & - & - & - & - & - & - & - & - & $\begin{array}{c}1.0 \\
(14.0)\end{array}$ \\
\hline Viscosia parasetosa & $2 \mathrm{~B}$ & $1.0(0.4)$ & - & - & - & - & - & - & - & - \\
\hline Viscosia tumidula & $2 \mathrm{~B}$ & - & - & - & - & $6.0(4.5)$ & - & $2.0(1.4)$ & - & - \\
\hline Total ind. $10 \mathrm{~cm}^{-2}$ & & 284 & 37 & 66 & 7 & 132 & 14 & 141 & 0 & 7 \\
\hline
\end{tabular}

${ }^{\mathrm{a}} 2.0(1.4)=$ Ind. $10 \mathrm{~cm}^{-2}$ (Percentage contribution).

The top three ranking species in station 5 were D. hirsutum, Daptonema normandicus and Trichotheristus erectus. Higher density of Pierickia vitielloi, Sabatieria heterura and Viscosia antartica were recorded while moving towards the low tide stations. Station 7 was dominated by $D$. hirsutum followed by Sphaerolaimus macrocirculus and $D$. tenuispiculum. However, no nematode was found in the samples taken from station 8.

Subtidal station (station 9) was dominated by Thalassomonhystera sp, Oxyonchus australis, Desmolorenzenia spec and Viscosia leptolaima. Generally, D. hirsutum was found dominant in several stations (mid tide to low tide stations). Daptonema was the dominant genera recorded in present study

\section{Nematode feeding group}

Nematodes were grouped into different functional feeding groups (FFG) (Figure $2 \mathrm{~b}$ and Table 2). Station 1 was dominated by nematodes from the feeding type of $2 \mathrm{~B}$ (predators) and least species from $1 \mathrm{~A}$ (selective deposit feeders). Station 2 was colonized by epigrowth or diatom feeders (2A). Nonselective deposit feeders (1B) were mostly found in station 3 and 4. 1B, 1A, 2B and 2A (according to ranking) were recorded in station 5 . Selective deposit feeders $(1 \mathrm{~A})$ was the dominant type in station 6 followed by the predators and non-selective deposit feeders. Station 7 was dominated by species with FFG of $1 \mathrm{~B}$ followed by $2 \mathrm{~B}, 2 \mathrm{~A}$ and $1 \mathrm{~A}$. Lastly, station 9 was recorded with nematodes from the FFG of $1 \mathrm{~A}$ and $2 \mathrm{~B}$. 
a)

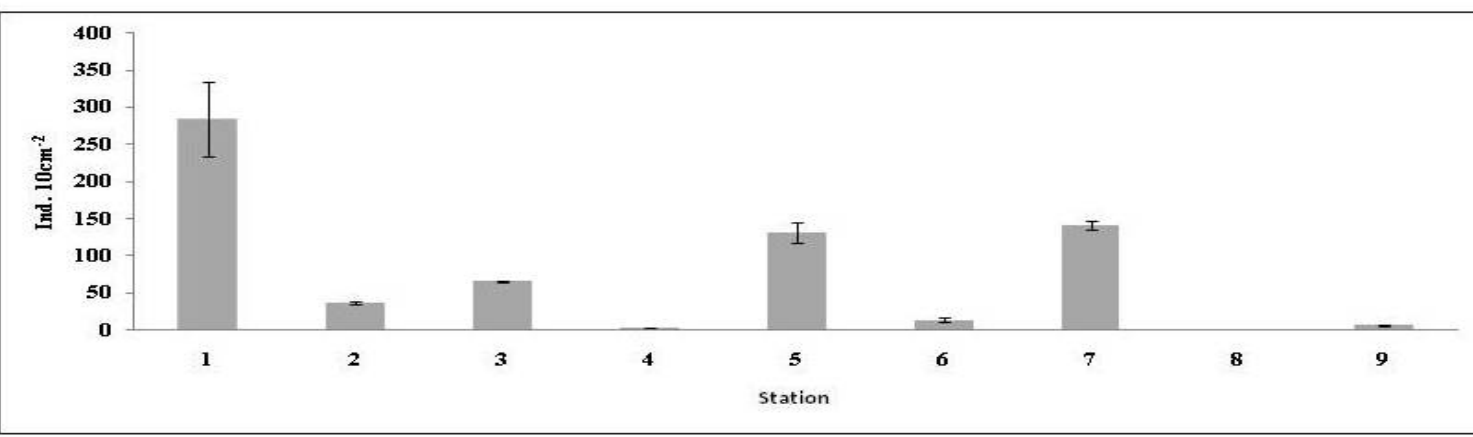

b)

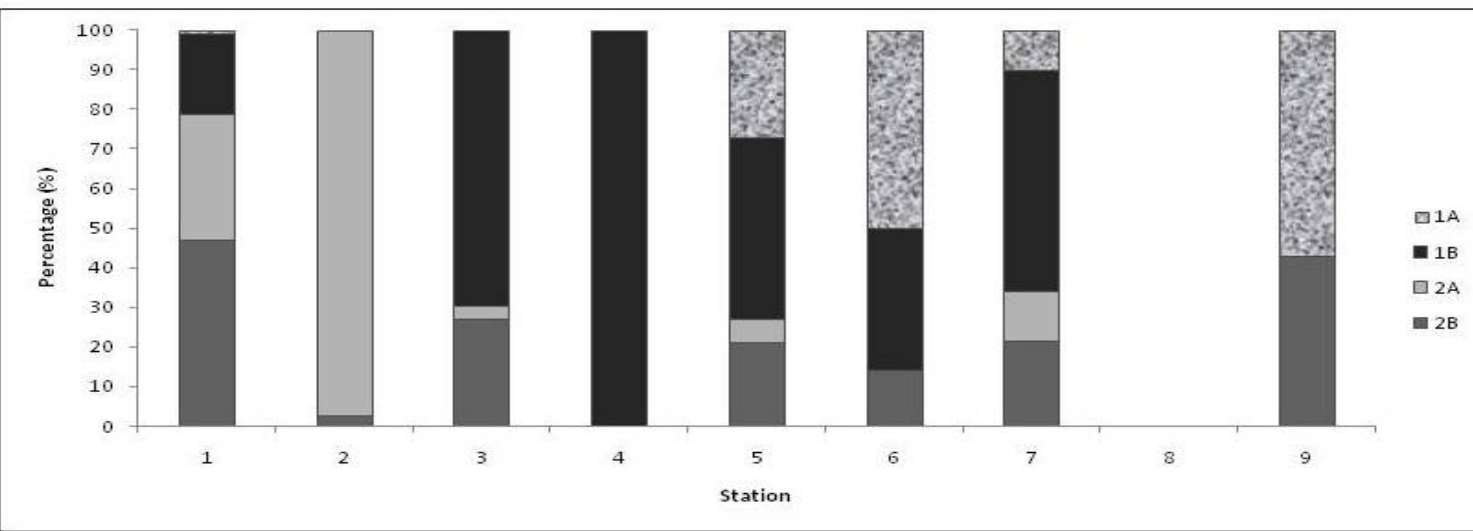

Figure 2. (a) Mean density \pm SD of nematodes (Ind. $10 \mathrm{~cm}^{-2}$ ) in each sampling station in Teluk Awar. (b) Percentage of nematode feeding type in each station at Teluk Awar.

\section{Nematodes community and distribution patterns}

A multi-dimensional scaling (nMDS) subjected to the Bray-Curtis similarity matrix was produced using the mean densities of each nematode species (Figure 3). The result of the nMDS showed that the stations in Teluk Awar were divided into three groups. Subtidal stations 8 and 9 were categorized as independent groups while the other intertidal stations were clustered together. Figure 4 demonstrated the similarity percentage of stations subjected to BrayCurtis similarity matrix. At 20\% similarity level, the stations were divided into 8 groups (Figure 4) which indicated high dissimilarity in species between the stations.

Biota and/or environment matching analysis had been used to determine the relationship between environmental variables and nematode species densities (subject to Spearman correlation). The combination of all studied environmental variables showed weak correlation with the nematode species densities (correlation $=0.208$ ). However, the combination of three environmental variables (clay, TOM and temperature) had affected the nematode densities in Teluk Awar (correlation = 0.604).

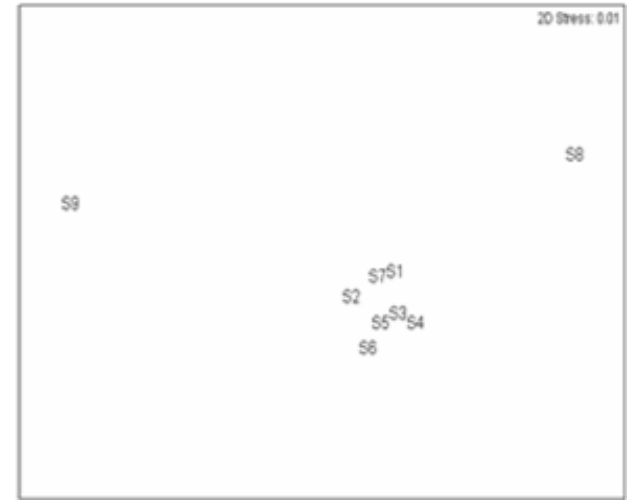

Figure 3. Multi-dimensional scaling subjected to the Bray-Curtis similarity matrix (stress level: 0.01 ).

\section{DISCUSSION}

Generally, the total density (Ind. $10 \mathrm{~cm}^{-2}$ ) of nematodes recorded in the present study is extremely low as compared to similar studies conducted in other tropical and temperate areas (Shabdin \& Othman 2008; Hourston et al. 2009). Within the intertidal stations, the results of the densities did not show any significant trend (increasing or decreasing steadily) while moving 
outward to the low tide stations. One of the possible explanations might be the patchiness phenomenon. According to Warwick et al. (1990), nematodes might be influenced by the minute habitat heterogeneities, temporal variations and food web interaction.

Chong (2000) mentioned that the health status of the Sarawak River is generally unsuitable for aquatic life (due to low DO). However, DO was not the primary factor that influenced the nematode density in the present study. Result showed that nematodes were scarcely found in the subtidal station 8 and 9 which comprised higher DO compared to the intertidal area stations. During sampling using SCUBA diving technique, both stations were recorded with an extreme low visibility together with high velocity of current. Confounding factor such as high velocity (hydrodynamic forces) probably contributed to the low density of nematode in the samples taken from the subtidal stations.

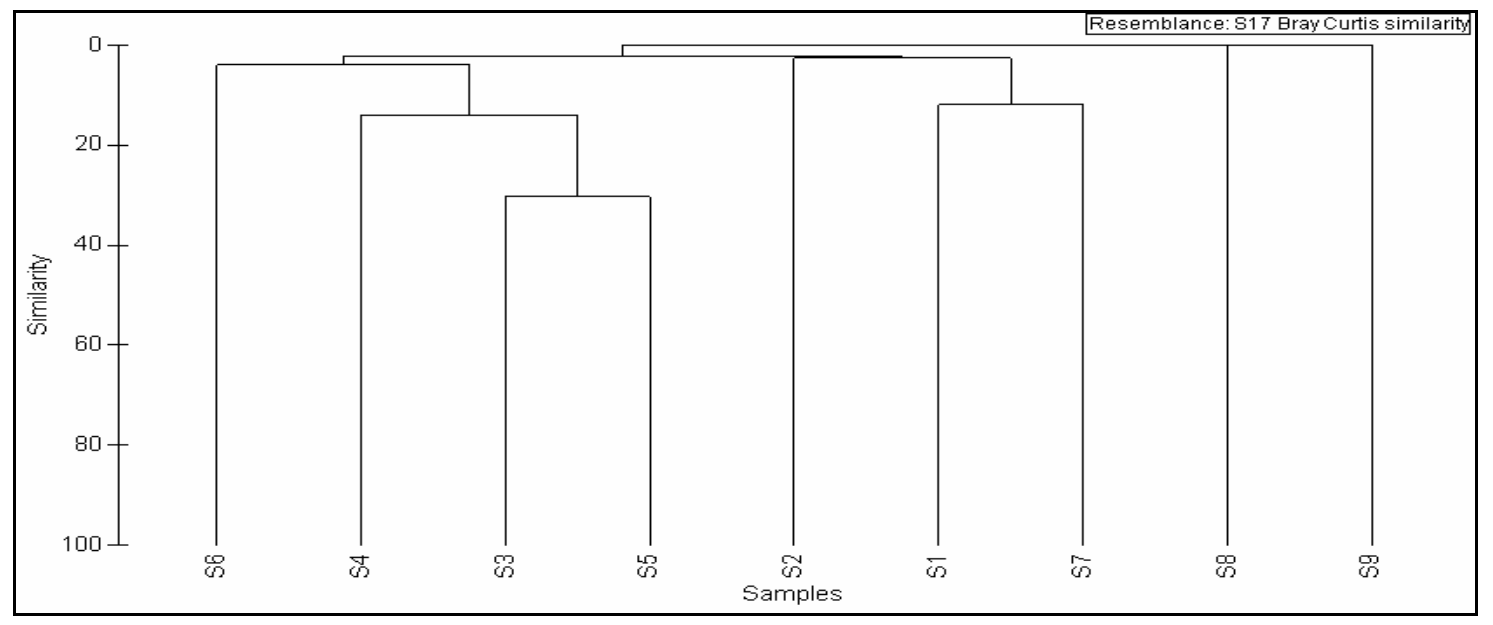

Figure 4. Dendrogram produced by cluster analysis showing the percentage of similarity between the stations.

The highest nematode density in this study was recorded in station 1 probably due to the influx of freshwater (associated with the nutrients) or hydrodynamic forces. The influx of freshwater from Sarawak River together with the decomposed leaves were suspected to enrich station 1 . This phenomenon potentially increases the density of marine nematode in station 1 due to the availability of food sources. In certain cases, the hydrodynamic forces are not to be overlooked (Shabdin 1985; Adão et al. 2009). The marine nematodes in station 1 probably drifted in by the wave current to station 1 during the flood tide. Besides that, Shabdin (1985) also mentioned that the hydrodynamic forces might lead to greater sediment mixing hence increase oxygenation on sandy and muddy areas.
Station 2 which was dominated by silt fraction and occupied by mangrove species showed lower diversity but higher abundance in certain species. In certain aspects, the phenomenon can be explained as those species might prefer the type of particles that has been localized in the specific stations. This is supported by the statistical analysis of biota and/or environment matching where clay fraction contributed to the distribution pattern of the marine nematode in Teluk Awar. Warwick (1971) mentioned that sediment particle size affects the distribution of the nematodes. Grain size is said to be the major factor influencing the species diversity of nematodes along the Sarawak coastal waters (Shabdin 2006). According to Steyaert et al. (2003), the predominance of sandy sediments contribute to a decrease in density and an increase in diversity because of wider range of microhabitats available for nematodes in the sediments when compared to the muddy ones. 
Temperature is determined to influence the community structure of marine nematode in the present study. Higher numbers of species density was recorded at the intertidal stations (higher temperature) compared to the subtidal stations. Besides that, the influences of temperature on the species density of the nematodes are recorded in several studies (Heip et al. 1985; Gheskiere et al. 2004; Shabdin \& Othman 2008). Temperature has a profound effect on minimum generation time $T_{\min }$ in all nematodes study (Warwick 1981).

TOM was identified as one of the components that affected the distribution pattern of marine nematode in Teluk Awar. TOM reading of station 3, 5 and 6 are higher compared to the other stations. The availability of TOM as the food source is most likely contributes to the patchiness of the nematode assemblages in the area. According to Santos et al. (2008), the nematodes' response to food availability and quality as well as to other environmental factors are highly species-specific and the food availability and quality are important factors contributing to the small-scale spatial distribution observed in nematode communities. Since the free-living species of nematode tend to be selective in the food they ingest, the presence of large amounts of particular food at a locality would favor colonization by species that belong to particular trophic groups (Hourston et al. 2009). The result shows that the studied area was dominated by the nematodes from the feeding type of $1 \mathrm{~B}$ (Non-selective deposit feeders) which was similar to the study carried out in Lok Kawi beach in Sabah (Shabdin \& Othman 2008). Station 3 was dominated by nematode species from the FFG of $1 B$. The occurrence of organic matter contributes to the food source for certain genus of marine nematode such as the non-selective deposit feeders (1B) Daptonema spp (Hourston et al. 2009) matching the findings of the present study where Daptonema spp were dominant in Teluk Awar.

\section{CONCLUSIONS}

A total of 22 genera and 63 species of nematodes were recorded in Teluk Awar. In general, total density (Ind. $10 \mathrm{~cm}^{-2}$ ) of nematodes is extremely low as compared to other tropical and temperate area. Several environmental parameters such as clay fraction, TOM and temperature are correlated with the distribution pattern of marine nematode assemblages in Teluk Awar.

\section{ACKNOWLEDGEMENTS}

The present study was carried out under the research grant FRGS Grant no. 07(03)/786/2010(67). We would like to thank Universiti Malaysia Sarawak for providing facilities, administrative and logistic supports during field work.

\section{REFERENCES}

Adão, H., Alves, A.S., Patricio, J., Neto, J.M., Costa, M.J., \& Marques, J.C. (2009). Spatial distribution of subtidal nematode communities along the salinity gradient in southern European estuaries. Acta Oecologica, 35: 287-300.

Alongi, D.M. (1990). Community dynamic of freeliving nematodes in some tropical mangrove and sandflat habitats. Bulletin of Marine Science, 46: 358-373.

Buchnan, J.B. (1984). Sediment analysis. In N.A. Holme, \& A.D. Mclntyre (Eds.), Methods for the study of marine benthos (pp. 41-65). United Kingdom: Blackwell Scientific Publications.

Chong, T.T. (2000). Making Sg. Sarawak free from pollution. In Conference report, 6 th interagency conference, 20-22 June 2000 (pp. 4448). Miri, Malaysia: State Planning Unit, Sarawak, Malaysia.

Dye, A.H. (1983). Vertical and horizontal distribution of meiofauna in mangrove sediment in Transkei, Southem Africa. Estuarine, Coastal and Shelf Science, 16: 591-598.

Forster, S.J. (1997). Osmotic stress tolerance and osmoregulation of intertidal and subtidal nematodes. Journal of Experimental Marine Biology and Ecology, 224: 109-125.

Gheskiere, T., Hoste, E., Vanaverbeke, J., Vincx, M., \& Degraer, S. (2004). Horizontal zonation patterns and feeding structure of marine nematode assemblages on a macrotidal, ultradissipative sandy beach (De Panne, Belgium). Journal of Sea Research, 52: 211-226.

Giere, O. (2009). Meiobenthology (The microscopic motile fauna of aquatic sediments). New York: Springer-Verlag Berlin Heidelberg. 527 pp. 
Greiser, N \& Faubel, A. (1988). Biotic factors. In R.P. Higgin, \& H. Thiel, (Eds.) Introduction to the study of meiofauna (pp. 79-114). Washington, D.C.: Smithsonian Institution Press.

Heip, C., Vincx M \& Vranken, G. (1985). The ecology of marine nematodes. Oceanography and Marine Biology: An Annual Review, 23: 399489.

Hourston, M., Potter, I.C., Warwick, R.M., Valesini, F.J. \& Clarke, K.R. (2009). Spatial and seasonal variations in the ecological characteristics of the free-living nematode assemblages in a large microtidal estuary. Estuarine, Coastal and Shelf Science, 82(2): 309-322.

Jeffrey, S.W. \& Humphrey, G.F. (1975). New spectrophotometric equations for determining chlorophylls a,b,c,c2 in higher plants, algae and natural phytoplankton. Biochemieund Physiologie der pflanzen, 167: 191-194.

Mahmoudi, E., Essid, N., Beyrem, H., Hedfi, A., Boufahja, F., Vitiello, P., \& Aissa, P. (2005). Effects on hydrocarbon contamination on a free living marine nematode community: results from microcosm experiments. Marine Pollution Bulletin, 50(11): 197-204.

Mahmoudi, E., Essid, N., Beyrem, H., Hedfi, A. Boufahja, F. Vitiello, P. \& Aissa, P. (2006). Individual and combined effects of lead and zinc on a free-living marine nematode community: results from microcosm experiments. Journal of Experimental Marine Biology and Ecology, 343: 217-226.

Moreno, M., Vezzulli, L., Marin, V., Laconi, P., Albertelli, G. \& Fabiano, M. (2008). The use of meiofauna as an indicator of pollution in harbours. Journal of Marine Science, 65: 14281435.

NREB, (2006). Sarawak annual water quality report 2005. Sarawawk, Malaysia: Natural Resource and Environment Board. p.34.

Ólaffsson, E. (1995). Meiobenthos in mangrove areas in eastern Africa with emphasis on assemblages structure of free-living marine nematodes. Hydrobiologia, 312: 47-57.

Platt, H.M. and Warwick, R.M. (1983). Freeliving marine nematodes. Part I. British Enoplids. In D.M. Kermack \& R.S.K. Barnes (Eds.), Synopses of the British Fauna No.28 Cambridge: Cambridge University Press, p 307.
Platt, H.M. and Warwick, R.M. (1988). Freeliving marine nematodes. Part II. British Chromadorids. In D.M. Kermack \& R.S.K. Barnes (Eds.), Synopses of the British Fauna No.38, Leiden: E.J. Brill/Dr Backhuys,. p 502.

Santos, G..A..P., Derycke, S., Fonseca-Genevois, V., Coelho., L., Correia, M. \& Moens, T. (2008). Differential effects of food availability on population growth and fitness of three species of estuarine, bacterial feeding nematodes. Journal of Experimental Marine Biology and Ecology, 355: 185-206.

Sasekumar, A. (1995). Meiofauna of a mangrove shore on the west coast of peninsular Malaysia. Raffles Bulletin of Zoology, 42: 901-915.

Shabdin, M.L. (1985). The impact of pollution on the meiofauna of an estuarine mudflat. MSc. Thesis, Heriot-Watt University, Edinburgh, Scotland. p. 239.

Shabdin, M.L. (2006). Marine and estuarine meiofauna of Sarawak, Malaysia - A Review. Sarawak Museum Journal, 83: 201-222.

Shabdin, M.L. \& Othman, B.H.R. (2008). Horizontal distribution of intertidal nematode from Sabah, Malaysia. Journal of Tropical Biology and Conservation, 4(1): 39-53.

Sommerfield, P.J., Warwick, R.M. \& Moens, T. (2005). Chapter 6: Meiofauna techniques. In: A. Eleftheriou \& A. McIntyre (Eds.) Methods for the study of marine benthos third edition (pp. 269-272). United Kingdom: Blackwell Scientific Publications.

Steyaert, M., Vanaverbeke, J.C., Vanreusel, A., Barranguet, C., Lucas, C., \& Vincx, M. (2003). The importance of fine-scale vertical profiles in characterizing nematode community structure. Estuarine, Coastal and Shelf Science, 58: 353366.

Tietjen, J.H. (1976). Distribution and species diversity of deep sea nematodes off North Carolina. Deep Sea Research, 23: 755-768.

Vermeeren, H., Vanreusel, A. \& Vanhove, S. (2004). Species distribution within the free-living marine nematode genus Dichromadora in the Weddell Sea and adjacent areas. Deep-sea Research II, 54: 1643-1664. 
Warwick, R.M. (1971). Nematode association in the Exe Estuarine. Journal of the Marine Biological Association of the United Kingdom, 51: 439-454.

Warwick, R.M. (1981). The influence of temperature and salinity on energy partitioning in the marine nematode Diplolaimelloides bruciei. Oecologia 51(3): 318-325.

Warwick, R.M. (1993). Environmental impact studies on marine communities: pragmatical considerations. Australian Journal of Ecology, 18: 63-80.
Warwick, R.M., Platt, H.M. \& Sommerfield, P.J. (1998). Free-living nematodes (Part III) Monhysterids. In R.S.K. Barnes, \& J.H. Crothers (Eds.), Synopsis of British Fauna, No. 53. (p.296). Shewsbury: Field Studies Council.

Warwick, R.M., Platt, H.M., Clarke, K.R., Agard, J., \& Gobin, J. (1990). Analysis of macrobenthic and meiobenthic community structure in relation to pollution and disturbance in Hamilton Harbour, Bermuda. Journal of Experimental Marine Biology and Ecology, 138: 119-142.

Wasmund, N. (1984). Probleme der spectropho tometrischen chlorophyllbestimmung. Acta Hydrochimica et Hydrobiologica, 12: 255-272. 